\title{
Article \\ Muscarinic Receptors and BK Channels Are Affected by Lipid Raft Disruption of Salivary Gland Cells
}

\author{
Jisoo Lee ${ }^{1,+}\left(\mathbb{D}\right.$, Yoon-Jung Kim ${ }^{1,+}$, La-Mee Choi ${ }^{1}$, Keimin Lee ${ }^{1,2}$, Hee-Kyung Park ${ }^{3, * \mathbb{C}}$ and Se-Young Choi ${ }^{1, * \mathbb{C}}$ \\ 1 Department of Physiology, Dental Research Institute, Seoul National University School of Dentistry, \\ Seoul 03080, Korea; jisulee@snu.ac.kr (J.L.); agi@snu.ac.kr (Y.-J.K.); friend0508@hanmail.net (L.-M.C.); \\ keimin@naver.com (K.L.) \\ 2 DSC Investment, Seoul 04779, Korea \\ 3 Department of Oral Medicine and Oral Diagnosis, Dental Research Institute, \\ Seoul National University School of Dentistry, Seoul 03080, Korea \\ * Correspondence: dentopark@snu.ac.kr (H.-K.P.); sychoi@snu.ac.kr (S.-Y.C.); \\ Tel.: +82-2-2072-2610 (H.-K.P.); +82-2-740-8650 (S.-Y.C.); \\ Fax: +82-2-744-9150 (H.-K.P.); +82-2-762-5107 (S.-Y.C.) \\ + These authors contributed equally to this study.
}

Citation: Lee, J.; Kim, Y.-J.; Choi,

L.-M.; Lee, K.; Park, H.-K.; Choi, S.-Y.

Muscarinic Receptors and BK Channels Are Affected by Lipid Raft Disruption of Salivary Gland Cells. Int. J. Mol. Sci. 2021, 22, 4780.

https://doi.org/10.3390/ijms22094780

Academic Editor: Sang-Gun Ahn

Received: 6 April 2021

Accepted: 28 April 2021

Published: 30 April 2021

Publisher's Note: MDPI stays neutral with regard to jurisdictional claims in published maps and institutional affiliations.

Copyright: (c) 2021 by the authors. Licensee MDPI, Basel, Switzerland. This article is an open access article distributed under the terms and conditions of the Creative Commons Attribution (CC BY) license (https:// creativecommons.org/licenses/by/ $4.0 /)$.

\begin{abstract}
Activity-dependent fluid secretion is the most important physiological function of salivary glands and is regulated via muscarinic receptor signaling. Lipid rafts are important for G-protein coupled receptor (GPCR) signaling and ion channels in plasma membranes. However, it is not well understood whether lipid raft disruption affects all membrane events or only specific functions in muscarinic receptor-mediated water secretion in salivary gland cells. We investigated the effects of lipid raft disruption on the major membrane events of muscarinic transcellular water movement in human salivary gland (HSG) cells. We found that incubation with methyl- $\beta$-cyclodextrin (M $\beta C D)$, which depletes lipid rafts, inhibited muscarinic receptor-mediated $\mathrm{Ca}^{2+}$ signaling in HSG cells and isolated mouse submandibular acinar cells. However, $\mathrm{M} \beta \mathrm{CD}$ did not inhibit a $\mathrm{Ca}^{2+}$ increase induced by thapsigargin, which activates store-operated $\mathrm{Ca}^{2+}$ entry (SOCE). Interestingly, $\mathrm{M} \beta \mathrm{CD}$ increased the activity of the large-conductance $\mathrm{Ca}^{2+}$-activated $\mathrm{K}^{+}$channel (BK channel). Finally, we found that $\mathrm{M} \beta \mathrm{CD}$ did not directly affect the translocation of aquaporin-5 (AQP5) into the plasma membrane. Our results suggest that lipid rafts maintain muscarinic $\mathrm{Ca}^{2+}$ signaling at the receptor level without directly affecting the activation of SOCE induced by intracellular $\mathrm{Ca}^{2+}$ pool depletion or the translocation of AQP5 into the plasma membrane.
\end{abstract}

Keywords: lipid raft; salivary gland; G-protein coupled receptor; BK channel; aquaporin-5; methylbeta-cyclodextrin

\section{Introduction}

Activity-dependent water secretion in exocrine glands is controlled precisely by external signals [1,2]. In particular, the regulation of aquaporin function, a type of water channel, has been studied intensively as a key mechanism of water secretion [3-6]. Exocrine gland cells use G-protein coupled receptors (GPCRs) to accept extracellular signals and regulate the translocation of aquaporin into the plasma membrane. For example, vasopressin receptors in renal-collecting duct cells induce cyclic adenosine monophosphate (cAMP) production, leading to the membrane translocation of aquaporin-2 (AQP2)/aquaporin-3 (AQP3) $[5,7]$. In the salivary gland, the $\mathrm{Ca}^{2+}$ signaling of GPCRs, including the muscarinic M3 receptor, induces membrane translocation of aquaporin-5 (AQP5) $[8,9]$.

The GPCR activation and subsequent translocation of aquaporin require well-organized signaling pathways that function based on environmental cues. The lipid raft is a cell membrane microdomain composed of cholesterol, glycolipids, sphingolipids, and specific proteins, which acts as the main center of signal transmission [10,11]. Lipid rafts 
play an important role in various cellular processes, such as signal transduction, protein trafficking, exocytosis, endocytosis, chemotaxis, and cell migration [12]. Particularly in cells with apical-basolateral polarity, lipid rafts have a significant impact on physiological functions [13]. These lipid rafts also contain receptors and ion channels [11,14]. Therefore, lipid rafts regulate various functions mediated by GPCRs, such as vasopressin receptors and muscarinic receptors.

In salivary gland cells, muscarinic receptor-mediated water movement is largely mediated by three membrane events. The first is the activation of the muscarinic receptor GPCR. The second is the store-operated $\mathrm{Ca}^{2+}$ entry (SOCE) after cytosolic $\mathrm{Ca}^{2+}$ pool depletion $[15,16]$ and the subsequent activation of $\mathrm{Ca}^{2+}$-activated ion channels controlling the membrane potential [17]. The third is the cytosolic $\mathrm{Ca}^{2+}$-dependent translocation of AQP5 into the plasma membrane [18,19]. Lipid rafts are considered to modulate these steps significantly; however, the role of lipid rafts in each step is not yet clearly understood, even though the role of lipid rafts in vasopressin receptor-mediated AQP2 translocation in the kidney has been relatively well studied.

In this report, we sought to determine the lipid raft dependency of each activitydependent AQP5 translocation step in salivary gland cells. Methyl- $\beta$-cyclodextrin $(\mathrm{M} \beta C D)$ disrupts lipid rafts by scavenging cholesterol [14,20]. We investigated the effects of $M \beta C D$ on muscarinic M3 receptor signaling and its downstream membrane events in human salivary gland cells.

\section{Results}

\section{1. $M \beta C D$ Preincubation Induced Cholesterol Depletion in HSG Cells}

$\mathrm{Ca}^{2+}$ signaling and aquaporin translocation in the HSG cell line have been used to study endocrine secretion mechanisms $[19,21,22]$. Therefore, we first confirmed whether $\mathrm{M} \beta C D$ treatment depletes cholesterol in HSG cells. The previous studies of the concentrationdependent manner of $\mathrm{M} \beta C D$ have revealed that $10 \mathrm{mM} \mathrm{M} \beta C D$ is enough for cholesterol depletion in M07e cells (human leukemia megakaryocytic cell line) [23] and B103 neuroblastoma cells [24]. Comparing cholesterol content at different $\mathrm{M} \beta C D$ concentrations showed that treatment with $10 \mathrm{mM} \mathrm{M} \beta C D$ for 30 min decreased the amount of cholesterol in HSG cells $\left(\mathrm{F}_{(3,8)}=9.51, p<0.01\right.$; Figure 1A). The incubation of HSG cells with $10 \mathrm{mM}$ $\mathrm{M} \beta C D$ for 30 min did not affect cell viability $\left(\mathrm{t}_{(4)}=0.36, p=0.73\right.$; Figure $\left.1 \mathrm{~B}\right)$. We tested the incubation time course of $\mathrm{M} \beta \mathrm{CD}$ and found that the most effective treatment time was 30-60 $\min \left(\mathrm{F}_{(5,12)}=75.83, p<0.001\right.$; Figure $\left.1 \mathrm{C}\right)$.
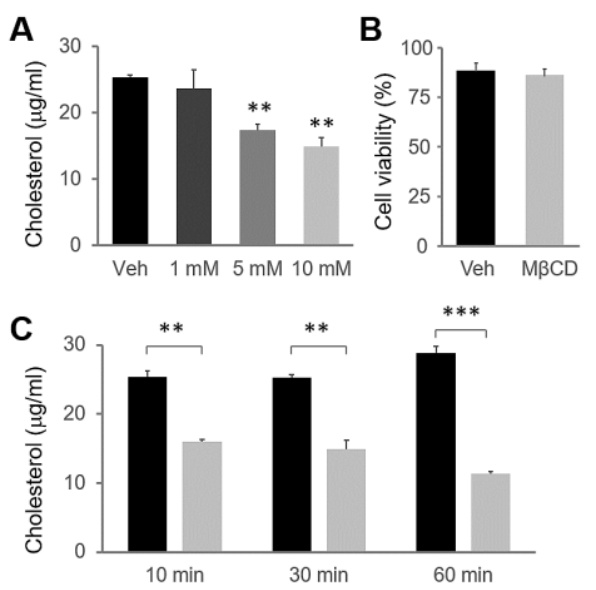

Figure 1. M $\beta C D$ depletes cholesterol in HSG cells. (A) HSG cells were incubated with the indicated concentration of M $\beta C D$ for $30 \mathrm{~min}$. (B) HSG cells were incubated with $10 \mathrm{mM} \mathrm{M} \beta C D$ for $30 \mathrm{~min}$ and then tested for cell viability using trypan blue assay. (C) The HSG cells were incubated with $10 \mathrm{mM}$ $\mathrm{M} \beta \mathrm{CD}$ for the indicated preincubation time. The cholesterol content of cell lysates is depicted as a percentage of the vehicle-treated control $(n=3) .{ }^{* *} p<0.01 ; * * * p<0.001$. 
2.2. $\mathrm{M} \beta C D$ Preincubation-Inhibited Muscarinic $\left[\mathrm{Ca}^{2+}\right]_{i}$ Increases without Any Effect on Thapsigargin-Mediated $\left[\mathrm{Ca}^{2+}\right]_{i}$ in Salivary Gland Cells

We next investigated the effect of $\mathrm{M} \beta C D$ treatment on intracellular $\mathrm{Ca}^{2+}$ signaling in HSG cells. A 30-min preincubation with $10 \mathrm{mM} \mathrm{M} \beta C D$ inhibited the $\left[\mathrm{Ca}^{2+}\right]_{\mathrm{i}}$ increase triggered by carbachol $\left(\mathrm{t}_{(2)}=16.37, p<0.01\right.$; Figure $\left.2 \mathrm{~A}\right)$. However, $\mathrm{M} \beta \mathrm{CD}$ incubation had no effect on the $\left[\mathrm{Ca}^{2+}\right]_{i}$ increase induced by thapsigargin, a sarcoplasmic reticular $\mathrm{Ca}^{2+}$-ATPase (SERCA) inhibitor $\left(\mathrm{t}_{(2)}=1.00, p=0.42\right.$; Figure $2 \mathrm{~B}$ ). We confirmed these results in isolated mouse submandibular gland acinar cells. As in the HSG cells, the carbacholmediated $\left[\mathrm{Ca}^{2+}\right]_{\mathrm{i}}$ increase was reduced in mouse submandibular acinar cells incubated with $\mathrm{M} \beta C D\left(\mathrm{t}_{(52)}=2.20, p<0.05\right)$ (Figure $\left.2 \mathrm{C}\right)$, whereas there was no difference in the thapsigargin-mediated $\left[\mathrm{Ca}^{2+}\right]_{\mathrm{i}}$ increase $\left(\mathrm{t}_{(60)}=0.09, p=0.93\right.$ ) (Figure 2D). Considering that thapsigargin depletes the intracellular calcium pool and induces SOCE, our results indicate that preincubation with $\mathrm{M} \beta C D$ suppresses only GPCR activation without affecting SOCE activity.

A

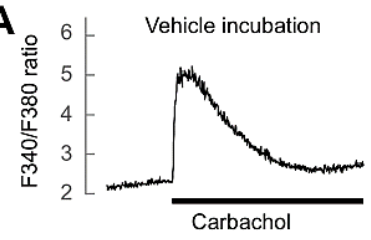

B

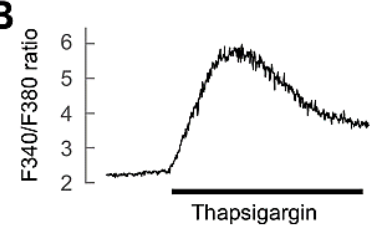

C

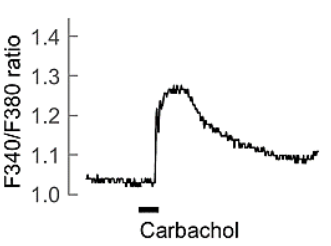

D

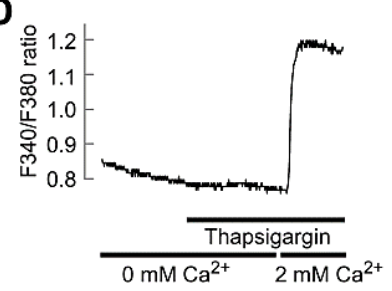

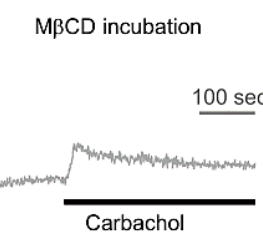

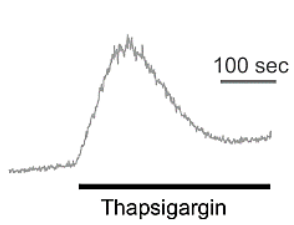

Thapsigargin
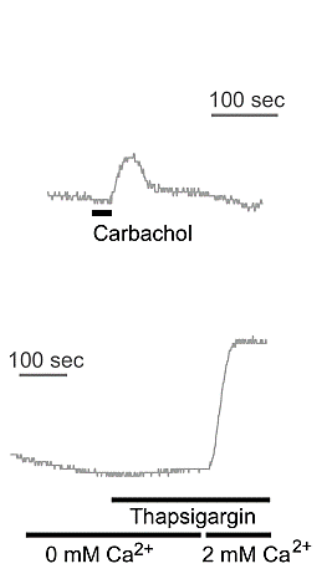
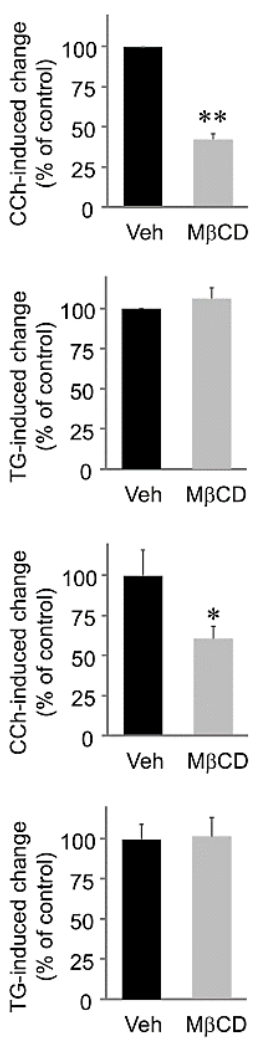

Figure 2. Preincubation with $\mathrm{M} \beta C D$ inhibits carbachol-induced $\mathrm{Ca}^{2+}$ increases but not thapsigargininduced $\mathrm{Ca}^{2+}$ increases. (A,B) Fura-2/AM-loaded HSG cells were treated with $100 \mu \mathrm{M}$ carbachol (A) or $1 \mu \mathrm{M}$ thapsigargin (B) with (black trace, left) or without (gray trace, right) preincubation with $10 \mathrm{mM} \mathrm{M} \beta C D$ for $30 \mathrm{~min}$. Typical $\mathrm{Ca}^{2+}$ transient experiments are shown. Quantification of F340/F380 changes $(n=3)$ induced by $100 \mu \mathrm{M}$ carbachol or $1 \mu \mathrm{M}$ thapsigargin preincubated with $10 \mathrm{mM} M \beta C D$. (C,D) Representative $\mathrm{Ca}^{2+}$ imaging traces in SMG cells isolated from mice. Cells were treated with $100 \mu \mathrm{M}$ carbachol with (black trace, $n=27$ cells) or without (gray trace, $n=27$ cells) $10 \mathrm{mM} \mathrm{M} \beta C D$ preincubation for $30 \mathrm{~min}$. Vehicle (black trace, $n=32$ cells) or M $\beta C D$ (gray trace, $n=30$ cells) preincubation cells were incubated in $\mathrm{Ca}^{2+}$-free buffer and stimulated with $1 \mu \mathrm{M}$ thapsigargin and then in $2.2 \mathrm{mM} \mathrm{Ca}^{2+}$-containing buffer. The results summary shows the percentage of all cells that responded to $\mathrm{CCh}$ or thapsigargin. Data are presented as mean $\pm \mathrm{SEM} .{ }^{*} p<0.05$; ** $p<0.01$. 


\section{3. $M \beta C D$ Preincubation Increased the BK Channel Activity in Salivary Gland Cells}

When $\left[\mathrm{Ca}^{2+}\right]_{i}$ is increased by GPCR activation in the salivary gland, a series of $\mathrm{Ca}^{2+}$ activated ion channels is activated. Large-conductance $\mathrm{Ca}^{2+}$-activated $\mathrm{K}^{+}(\mathrm{BK})$ channels are present in the cholesterol-enriched lipid raft domain [25]. We monitored changes in BK channel activity by cholesterol depletion in isolated mouse submandibular gland acinar cells using whole-cell patch-clamp recording. Interestingly, the preincubation of cells with $10 \mathrm{mM} \mathrm{M} \beta C D$ for 30 min increased $\mathrm{K}^{+}$currents (Figure $3 \mathrm{~A}$ ), which were inhibited by the BK inhibitor paxilline $\left(\mathrm{M} \beta C D, \mathrm{~F}_{(1,38)}=17.99, p<0.001\right.$; paxilline, $\mathrm{F}_{(1,38)}=59.41, p<0.001$; $\mathrm{mV}, \mathrm{F}_{(9,342)}=127.19, p<0.001$ ) (Figure $3 \mathrm{~B}$ ). These results imply that salivary BK channel activity is increased by lipid raft disruption.
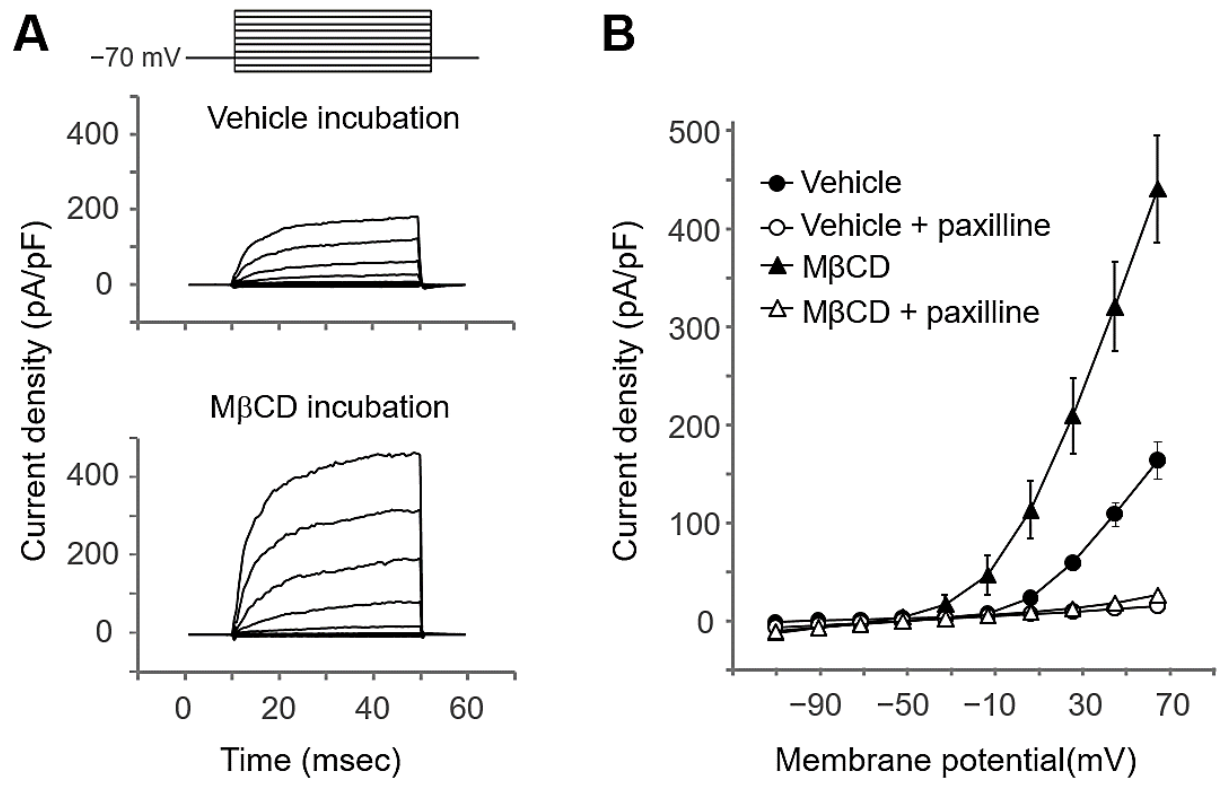

Figure 3. Preincubation with $M \beta C D$ increases $B K$ channel currents in mouse single SMG cells. (A) Typical current traces obtained in the control cells and those preincubated with $10 \mathrm{mM} \mathrm{M} \beta C D$ for $30 \mathrm{~min}$. Currents were recorded immediately (15-20 s) after achieving whole-cell mode. (B) Average I-V relations of current amplitudes measured at the end of $40 \mathrm{~ms}$ pulses to the indicated potentials in the absence $(\bullet)$ or presence $(\boldsymbol{\Delta})$ of $10 \mathrm{mM} \mathrm{M} \beta C D$. Open circle $(\bigcirc)$ and open triangle $(\triangle)$ plots were obtained after the addition of $1 \mu \mathrm{M}$ paxilline, a BK channel inhibitor. Each point represents the mean \pm SEM ( $n=10$ or 11$)$. The pulse protocol is shown as the graph insert.

\subsection{M $B C D$ Preincubation Did Not Directly Affect AQP5 Translocation in Salivary Gland Cells}

Muscarinic $\mathrm{Ca}^{2+}$ signaling triggers the membrane translocation of AQP5, a water channel protein in the salivary glands $[22,26,27]$. To determine the effect of $\mathrm{M} \beta C D$ on aquaporins, we analyzed the expression level of AQP5 via GFP intensity in the membrane fraction. In a previous study, we confirmed that $20 \mathrm{~min}$ of carbachol treatment was optimal for confirming activity-dependent AQP5 translocation [28]. We prepared the membrane fraction of HSG cells and analyzed the level of AQP5 in comparison with $\mathrm{Na}^{+} / \mathrm{K}^{+}$ exchanger, a membrane-enriched protein. We found that $\mathrm{M} \beta C D$ treatment marginally decreased the carbachol-induced AQP5 translocation $\left(\mathrm{F}_{(3.8)}=1.82, p=0.22\right.$; Figure $\left.4 \mathrm{~A}\right)$. Interestingly, $\mathrm{M} \beta \mathrm{CD}$ treatment did not inhibit thapsigargin-induced $\mathrm{AQP} 5$ translocation $\left(\mathrm{F}_{(3.8)}=1.60, p=0.26\right.$; Figure $\left.4 \mathrm{~B}\right)$. A flow cytometry experiment showed that a similar manner of AQP5 translocation was observed in the mouse isolated SMG cells (Figure 4C,D). These results suggest that the $\mathrm{M} \beta \mathrm{CD}$-mediated change in the salivary AQP5 translocation was mainly due to the decrease in the muscarinic receptor-induced $\mathrm{Ca}^{2+}$ signaling. 

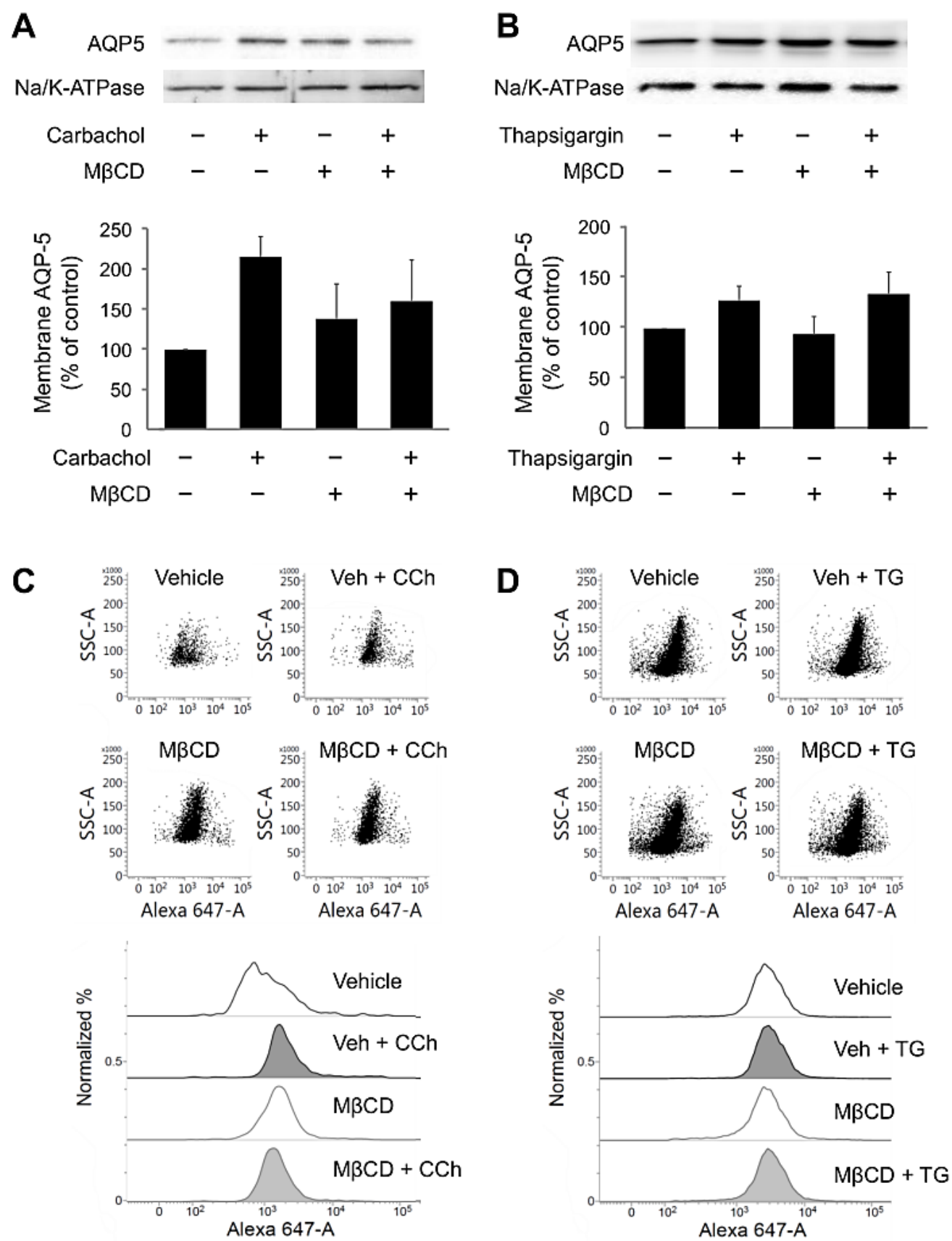

Figure 4. $M \beta C D$ incubation does not directly affect AQP5 translocation. (A,B) HSG cells transfected with GFP-tagged AQP5 were preincubated in either the absence or presence of $10 \mathrm{mM} \mathrm{M} \beta C D$ for $30 \mathrm{~min}$ and then challenged with $100 \mu \mathrm{M}$ carbachol (A) or $1 \mu \mathrm{M}$ thapsigargin (B). (Top) Western blots show membrane AQP5 and $\mathrm{Na}^{+}-\mathrm{K}^{+}$-ATPase. (Bottom) Quantification of membrane AQP5 with $\mathrm{Na}^{+}-\mathrm{K}^{+}$-ATPase control $(n=3$ to 6$)$. n.s. = not significant. (C,D) Representative dot plots and histograms from flow cytometry analysis represent the surface expression of AQP5 in the mouse isolated SMG cell. The cells were treated with or without $10 \mathrm{mM} \mathrm{M} \beta C D$ preincubation for $30 \mathrm{~min}$ and then challenged with $100 \mu \mathrm{M}$ carbachol (C) or $1 \mu \mathrm{M}$ thapsigargin (D).

\section{Discussion}

The physiological role of lipid rafts to optimize the functional cellular environment by maintaining membrane protein location and proximity between key functional players has received much scientific attention. In particular, the lipid raft mediates the physical association of GPCRs and downstream signal transduction factors. Thus, the lipid raft is 
more important in salivary cells that function based on polarity and those that function through several membrane events compared to their counterparts. However, the effects of the lipid raft on membrane events in salivary glands have not yet been clearly determined.

In this study, we aimed to understand the role of lipid rafts in salivary function. Muscarinic $\mathrm{M} 3$ receptor-mediated $\mathrm{Ca}^{2+}$ signaling plays an important role in AQP5 translocation in salivary gland cells $[22,29]$. The muscarinic mechanism in the plasma membrane includes $\mathrm{M} 3$ receptor activation, SOCE activation, and AQP5 translocation. In addition, muscarinic $\mathrm{M} 1$ and $\mathrm{M} 3$ receptors and (voltage-gated) $\mathrm{K}^{+}$channels exist in the membrane lipid raft and functionally couple in neurons [11] and HEK cells [30]. In addition, a BK channel also exists in the lipid raft [31-33]. We think that the muscarinic receptors and BK channels of salivary gland cells also exist in the lipid raft. Our results show that $\mathrm{M} \beta C D$-mediated lipid raft depletion inhibited carbachol-induced intracellular $\mathrm{Ca}^{2+}$ increase (Figure 2). The effect of lipid rafts on GPCR activation has been reported in many cells with frequent signal transduction (e.g., neurons). Lipid rafts have been reported to regulate N-methyl-D-aspartate receptor stabilization and receptor expression [34-36]. We also have reported that lipid rafts are important for AMPA receptor trafficking in a previous study [37]. Our results suggest that lipid rafts optimize GPCR signaling in salivary gland cells.

Interestingly, our findings reveal that the thapsigargin-triggered $\mathrm{Ca}^{2+}$ increase was not affected by $M \beta C D$ (Figure 2C). Thapsigargin is a sarco/endoplasmic reticulum calciumATPase (SERCA) inhibitor that induces $\mathrm{Ca}^{2+}$ pool depletion by inhibiting recharge of the cytosolic $\mathrm{Ca}^{2+}$ pool and subsequently inducing SOCE without GPCR activation. Thus, our findings of different inhibitory effects on carbachol and thapsigargin imply that the lipid raft inhibits GPCR activation without affecting SOCE activity. However, there have been several previous reports that SOCE is affected by lipid rafts [38-40]. We suspect this discrepancy is due to the difference in SOCE characteristics. Despite the commonality of the triggering mechanism (i.e., intracellular $\mathrm{Ca}^{2+}$ pool depletion), SOCE characteristics depend on cell type. SOCE is mediated by a series of factors, including TRPC1, Orai1, and STIM1 [41]. We have previously observed that thapsigargin-induced SOCE in PC12 cells is different from those in HL-60 cells and Jurkat T cells [42]. Therefore, we concluded that lipid rafts do not affect SOCE in salivary gland cells.

We found that the disruption of lipid rafts, which caused a decrease in muscarinic receptor function in HSG cells (Figure 2), increased BK channel activity (Figure 3). It has previously been shown that cholesterol modulates BK channel activity by controlling lipid rafts [43]. The cholesterol depletion-mediated increase in BK channel current activity has been found in IGR39 human melanoma cells [32] and rat vascular smooth muscle cells $[33,44]$. It has been reported that cholesterol treatment reduces the open probability of the BK channel in rat cerebral artery myocytes [45]. However, it also has been reported that the BK channel current was decreased by M $\beta C D$ in D54-MG and U251 glioma cell lines [31], implying that the relationship between lipid rafts and BK channel activity depends on cell type. Disruption of the cholesterol-enriched lipid raft structure is expected to modulate the activity by controlling the gating of the BK channel [25], but a clearer understanding of the molecular mechanism remains to be elucidated.

Finally, we examined the effect of lipid raft depletion on AQP5 translocation to the plasma membrane. Interestingly, M $\beta C D$ inhibited carbachol-induced AQP5 translocation but did not affect thapsigargin-induced AQP5 translocation (Figure 3). Given that $\mathrm{M} \beta C D$ did not cause a thapsigargin-induced $\mathrm{Ca}^{2+}$ increase or an increase in AQP5 translocation, our results indicate that the lipid raft does not affect the translocation of AQP5. It has been reported that lipid rafts are involved in targeting aquaporins [46], and the colocalization of the lipid raft markers flotillin and AQP5 is increased during treatment with muscarinic receptor agonists and $\mathrm{Ca}^{2+}$ ionophores [19]. However, it is unclear how lipid rafts affect these sequential events in membranes (i.e., from muscarinic receptor activation to AQP5 translocation). Our results clearly show that $\mathrm{M} \beta C D$ inhibits carbachol-induced AQP5 translocation, mainly at the receptor level. 
Lipid-lowering medications prescribed for hypercholesterolemia to lower blood cholesterol include HMG-CoA reductase inhibitors, commonly referred to as statins [47]. Interestingly, it has been reported that xerostomia, along with lichenoid and aphthae, is frequently found in patients receiving a statin prescription [48]. In addition, when statin treatment was stopped in dry mouth patients undergoing statin treatment, dry mouth symptoms were found to be relieved [49]. Our results, elucidating the relationship between cholesterol-depletion and salivary signaling, strongly suggest the causative mechanism of dry mouth in lipid-lowering medications.

Taken together, we examined the effects of lipid rafts on muscarinic signaling and found that lipid rafts regulate GPCRs and BK channels in the salivary gland cells. Our study will help others understand the molecular target of the lipid raft on the muscarinic signaling-mediated water secretion and will contribute to a better understanding of the cellular and molecular mechanisms of lipid rafts in modulating exocrine functions.

\section{Materials and Methods}

\subsection{Reagents}

Carbachol, $\mathrm{M} \beta \mathrm{CD}$, and thapsigargin were purchased from Sigma (St. Louis, MO, USA), and fura-2-acetoxymethyl ester (fura-2/AM) was obtained from Molecular Probes (Eugene, OR, USA). Dulbecco's Modified Eagle Medium (DMEM), fetal bovine serum, and penicillin/streptomycin were purchased from GIBCO (Grand Island, NY, USA). The antibodies acquired from commercial sources were as follows: aquaporin-5 goat polyclonal IgG (Santa Cruz, sc-9891, 1:1000, Dallas, TX, USA), anti-alpha 1 sodium-potassium ATPase (Abcam, ab7671) primary antibody, donkey anti-goat IgG-HRP (Santa Cruz, sc-2020, 1:10,000), and goat anti-mouse IgG-HRP (Santa Cruz, sc-2031, 1:10,000) secondary antibody.

\subsection{Cell Preparation}

A human salivary gland (HSG) ductal cell line [50] was grown in DMEM supplemented with $10 \%(v / v)$ heat-inactivated fetal bovine serum and $1 \%(v / v)$ penicillin $(5000 \mathrm{U} / \mathrm{mL})$ and streptomycin $(5000 \mu \mathrm{g} / \mathrm{mL})$. The cells were cultured in a humidified atmosphere of $95 \%$ room air and $5 \% \mathrm{CO}_{2}$. The culture medium was changed every two days, and the cells were sub-cultured weekly. Isolated mouse submandibular gland acinar cells were prepared as previously reported [17]. Briefly, mouse submandibular glands were surgically removed, finely minced with scissors, and digested for $5 \mathrm{~min}$ in $0.02 \%$ trypsin-EDTA (GIBCO) and $0.5 \mathrm{mg} / \mathrm{mL}$ collagenase (Sigma) in DMEM. The cells were triturated and centrifuged at $190 \times g$ for $1 \mathrm{~min}$ and then washed twice with serum-free DMEM. Acinar cells were attached to poly D-lysine-coated glass coverslips.

\subsection{Cytosolic Free $\mathrm{Ca}^{2+}$ Measurement}

The cytosolic free $\mathrm{Ca}^{2+}$ concentration $\left(\left[\mathrm{Ca}^{2+}\right]_{\mathrm{i}}\right)$ was determined using the fluorescent $\mathrm{Ca}^{2+}$ indicator fura-2/AM, as previously described $[27,28]$. Briefly, the cell suspension was incubated in fresh medium containing fura-2/AM $(4 \mu \mathrm{M})$ for 60 min at $37^{\circ} \mathrm{C}$ with continuous stirring. Cells on coverslips were mounted onto the inverted microscope (Olympus IX70, Tokyo, Japan) and perfused continuously at $2 \mathrm{~mL} / \mathrm{min}$ by a bath solution containing $140 \mathrm{mM} \mathrm{NaCl}, 5 \mathrm{mM} \mathrm{KCl}, 1 \mathrm{mM} \mathrm{MgCl}, 2 \mathrm{mM} \mathrm{CaCl}_{2}, 10 \mathrm{mM}$ HEPES, and $10 \mathrm{mM}$ glucose (pH 7.2). Fluorescence ratios were monitored with dual excitation at $340 \mathrm{~nm}$ and $380 \mathrm{~nm}$ and emission at $500 \mathrm{~nm}$.

\subsection{Cholesterol Measurement}

Cellular and plasma membrane cholesterol levels were determined using the Amplex Red Cholesterol Assay Kit (Molecular Probes) based on an enzyme-coupled reaction that detects both free cholesterol and cholesteryl esters, according to the manufacturer's instructions. In brief, a 50- $\mu \mathrm{L}$ sample was mixed with $50 \mu \mathrm{L}$ Amplex Red Reagent containing $2 \mathrm{U} / \mathrm{mL} \mathrm{HRP}, 2 \mathrm{U} / \mathrm{mL}$ cholesterol oxidase, and $0.2 \mathrm{U} / \mathrm{mL}$ cholesterol esterase and incubated at $37^{\circ} \mathrm{C}$ for $30 \mathrm{~min}$. Fluorescence was measured using an Epoch2 microplate 
spectrophotometer (Bio-Tek, Winooski, VT, USA) using an excitation and emission of $530 \mathrm{~nm}$ and $590 \mathrm{~nm}$, respectively.

\subsection{Cell Viability Assay}

Cell viability was determined using the trypan blue exclusion assay [24]. The HSG cells were treated with $10 \mathrm{mM} \mathrm{M} \beta C D$ for $30 \mathrm{~min}$, harvested, and added to $0.4 \%$ trypan blue (Sigma). The percentage of viable (trypan blue-unstained) cells was measured by counting the cells under the microscope. All counts were performed in triplicate.

\subsection{Electrophysiological Recording}

Whole-cell patch-clamp recordings were obtained using a HEKA EPC-9 amplifier (HEKA Elektronik, Lambrecht, Germany). The patch pipettes (3-6 M $\Omega$ resistance) were filled with $135 \mathrm{mM}$ K-glutamate, $5 \mathrm{mM}$ EGTA, $3 \mathrm{mM} \mathrm{CaCl}_{2}$, and $10 \mathrm{mM}$ HEPES, $\mathrm{pH}$ 7.2. The external solution contained $150 \mathrm{mM}$ Na-glutamate, $5 \mathrm{mM} \mathrm{K}$-glutamate, $2 \mathrm{mM}$ $\mathrm{CaCl}_{2}, 2 \mathrm{mM} \mathrm{MgCl}$, and $10 \mathrm{mM}$ HEPES, $\mathrm{pH}$ 7.2. The stimulation protocol to generate current-voltage (I-V) relationships consisted of 40-ms voltage steps from -110 to $+70 \mathrm{mV}$ in 20-mV increments starting from a holding potential of $-60 \mathrm{mV}$. Data were acquired and analyzed using PATCHMASTER software (HEKA Elektronik).

\subsection{Preparation of Membrane Fractions and Western Blotting}

The HSG cells were transiently transfected with the pEGFP-C1-AQP-5 plasmid using Lipofectamine 2000 [27]. AQP-5-transfected HSG cells were grown in a 60-mm dish, pre-incubated with $\mathrm{M} \beta C \mathrm{CD}$ for $3 \mathrm{~min}$, and treated with carbachol or thapsigargin for $20 \mathrm{~min}$ at $37^{\circ} \mathrm{C}$. The membrane fraction was obtained as previously described [28] and sonicated in ice-cold $20 \mathrm{mM}$ HEPES solution containing $1 \mathrm{mM} \mathrm{MgCl} 2,100 \mathrm{mM} \mathrm{NaCl}, 1 \mathrm{mM}$ dithiothreitol, and $0.3 \mathrm{mM}$ phenylmethylsulfonyl fluoride $(3 \times 30 \mathrm{~s}$; Sigma) at $\mathrm{pH}$ 7.4. The samples were centrifuged at $600 \times g$ at $4{ }^{\circ} \mathrm{C}$, and the supernatants were centrifuged further at $20,000 \times g$ at $4{ }^{\circ} \mathrm{C}$. The pellets (P2 membrane fractions) were separated via SDS-PAGE, and the proteins were transferred onto a PVDF membrane for immunoblotting. After blocking, the membrane was incubated with anti-AQP-5 (Santa Cruz, sc-9891, 1:200) as the primary antibody. The membrane was washed, incubated with donkey anti-goat IgG-HRP, and subjected to an electrochemiluminescence assay for detection. For normalization of the AQP5 signal, the membranes were stripped and re-probed with antibodies for anti- $\alpha 1$ $\mathrm{Na}^{+} / \mathrm{K}^{+}$-ATPase (Abcam, ab7671, 1:1000).

\subsection{Analysis of AQP5 Protein Expression by Flow Cytometry}

To evaluate the translocated AQP5 surface expression, we used flow cytometry in non-permeabilized cells performed as reported previously [51]. Briefly, mice SMG single cells were obtained by mashing using a $100 \mu \mathrm{m}$ cell strainer, followed by washing the cell strainer twice with $5 \mathrm{~mL}$ of $0.5 \%$ bovine serum albumin (BSA) in PBS. The cells were then centrifuged at $190 \times g$ and washed twice with $0.5 \%$ BSA in phosphate-buffered saline (PBS). The cells were fixed with $4 \%$ formaldehyde, washed, and blocked $2 \%$ BSA in PBS. After blocking, the cells were washed and resuspended in $100 \mu \mathrm{L}$ Alexa Fluor 647 conjugatedAQP5 antibody (Abcam, ab215225, 1:500), and incubated for $30 \mathrm{~min}$ at $4{ }^{\circ} \mathrm{C}$ in the dark. All of the washing steps were carried out using $1 \%$ FBS in PBS as washing buffer, followed by centrifugation ( $8000 \mathrm{rpm}, 1 \mathrm{~min}, 4^{\circ} \mathrm{C}$ ). The labeled cells were kept on ice until analysis. The cell samples were then acquired on a FACSVerse flow cytometer equipped with FACSUITE software (BD Biosciences, San Jose, CA, USA).

\subsection{Data Analysis}

All quantitative data are expressed as mean \pm SEM. Differences were determined by one-way analysis of variance (ANOVA) and considered significant when $p<0.05$.

Author Contributions: Conceptualization, S.-Y.C. and H.-K.P., methodology, J.L., K.L. and L.-M.C.; validation, J.L. and Y.-J.K.; formal analysis, J.L. and Y.-J.K.; investigation, J.L., K.L. and L.-M.C.; 
resources, J.L., K.L. and L.-M.C.; data curation, J.L. and Y.-J.K.; writing-original draft preparation, S.-Y.C. and H.-K.P. supervision, S.-Y.C. and H.-K.P. funding acquisition, S.-Y.C., Y.-J.K. and H.-K.P. All authors have read and agreed to the published version of the manuscript.

Funding: This work was supported by the National Research Foundation of Korea (2018R1A5A2024418 to S.Y.C.; 2021R1A2C2005573 to H.K.P.; 2021R1C1C2011217 to Y.J.K.), and the SNUDH Research Fund (07-2019-0007 to H.K.P.).

Institutional Review Board Statement: Not applicable.

Informed Consent Statement: Not applicable.

Conflicts of Interest: The authors declare no conflict of interest.

\section{References}

1. Dartt, D.A. Neural regulation of lacrimal gland secretory processes: Relevance in dry eye diseases. Prog. Retin. Eye Res. 2009, 28, 155-177. [CrossRef]

2. Proctor, G.B.; Carpenter, G.H. Regulation of salivary gland function by autonomic nerves. Auton. Neurosci. 2007, 133, 3-18. [CrossRef] [PubMed]

3. Brown, D.; Hasler, U.; Nunes, P.; Bouley, R.; Lu, H.A. Phosphorylation events and the modulation of aquaporin 2 cell surface expression. Curr. Opin. Nephrol. Hypertens. 2008, 17, 491-498. [CrossRef] [PubMed]

4. Kitchen, P.; Day, R.E.; Salman, M.M.; Conner, M.T.; Bill, R.M.; Conner, A.C. Beyond water homeostasis: Diverse functional roles of mammalian aquaporins. Biochim. Biophys. Acta 2015, 1850, 2410-2421. [CrossRef]

5. Olesen, E.T.; Fenton, R.A. Aquaporin-2 membrane targeting: Still a conundrum. Am. J. Physiol. Renal Physiol. 2017, 312, F744-F747. [CrossRef]

6. King, L.S.; Kozono, D.; Agre, P. From structure to disease: The evolving tale of aquaporin biology. Nat. Rev. Mol. Cell Biol. 2004, 5, 687-698. [CrossRef]

7. Valenti, G.; Procino, G.; Tamma, G.; Carmosino, M.; Svelto, M. Minireview: Aquaporin 2 trafficking. Endocrinology 2005, 146, 5063-5070. [CrossRef] [PubMed]

8. Delporte, C. Aquaporins in salivary glands and pancreas. Biochim. Biophys. Acta 2014, 1840, 1524-1532. [CrossRef] [PubMed]

9. Tada, J.; Sawa, T.; Yamanaka, N.; Shono, M.; Akamatsu, T.; Tsumura, K.; Parvin, M.N.; Kanamori, N.; Hosoi, K. Involvement of vesicle-cytoskeleton interaction in AQP5 trafficking in AQP5-gene-transfected HSG cells. Biochem. Biophys. Res. Commun. 1999, 266, 443-447. [CrossRef] [PubMed]

10. Aureli, M.; Grassi, S.; Prioni, S.; Sonnino, S.; Prinetti, A. Lipid membrane domains in the brain. Biochim. Biophys. Acta 2015, 1851, 1006-1016. [CrossRef]

11. Sebastiao, A.M.; Colino-Oliveira, M.; Assaife-Lopes, N.; Dias, R.B.; Ribeiro, J.A. Lipid rafts, synaptic transmission and plasticity: Impact in age-related neurodegenerative diseases. Neuropharmacology 2013, 64, 97-107. [CrossRef]

12. Simons, K.; Sampaio, J.L. Membrane organization and lipid rafts. Cold Spring Harb. Perspect. Biol. 2011, 3, a004697. [CrossRef]

13. Schuck, S.; Simons, K. Polarized sorting in epithelial cells: Raft clustering and the biogenesis of the apical membrane. J. Cell Sci. 2004, 117 Pt 25, 5955-5964. [CrossRef] [PubMed]

14. Allen, J.A.; Halverson-Tamboli, R.A.; Rasenick, M.M. Lipid raft microdomains and neurotransmitter signalling. Nat. Rev. Neurosci. 2007, 8, 128-140. [CrossRef]

15. Ambudkar, I.S. Calcium signalling in salivary gland physiology and dysfunction. J. Physiol. 2016, 594, 2813-2824. [CrossRef]

16. Pani, B.; Liu, X.; Bollimuntha, S.; Cheng, K.T.; Niesman, I.R.; Zheng, C.; Achen, V.R.; Patel, H.H.; Ambudkar, I.S.; Singh, B.B. Impairment of TRPC1-STIM1 channel assembly and AQP5 translocation compromise agonist-stimulated fluid secretion in mice lacking caveolin1. J. Cell Sci. 2013, 126 Pt 2, 667-675. [CrossRef]

17. Romanenko, V.G.; Nakamoto, T.; Srivastava, A.; Begenisich, T.; Melvin, J.E. Regulation of membrane potential and fluid secretion by $\mathrm{Ca}_{2+}$-activated $\mathrm{K}^{+}$channels in mouse submandibular glands. J Physiol. 2007, 581 Pt 2, 801-817. [CrossRef]

18. Ishikawa, Y.; Cho, G.; Yuan, Z.; Inoue, N.; Nakae, Y. Aquaporin-5 water channel in lipid rafts of rat parotid glands. Biochim. Biophys. Acta 2006, 1758, 1053-1060. [CrossRef] [PubMed]

19. Ishikawa, Y.; Yuan, Z.; Inoue, N.; Skowronski, M.T.; Nakae, Y.; Shono, M.; Cho, G.; Yasui, M.; Agre, P.; Nielsen, S. Identification of AQP5 in lipid rafts and its translocation to apical membranes by activation of M3 mAChRs in interlobular ducts of rat parotid gland. Am. J. Physiol. Cell Physiol. 2005, 289, C1303-C1311. [CrossRef]

20. Koudinov, A.R.; Koudinova, N.V. Essential role for cholesterol in synaptic plasticity and neuronal degeneration. FASEB J. 2001, 15, 1858-1860. [CrossRef] [PubMed]

21. Jin, M.; Hwang, S.M.; Koo, N.Y.; Kim, B.; Kho, H.S.; Choi, S.Y.; Song, Y.W.; Park, K. Autoantibodies in Sjogren's syndrome patients acutely inhibit muscarinic receptor function. Oral Dis. 2012, 18, 132-139. [CrossRef] [PubMed]

22. Lee, B.H.; Gauna, A.E.; Perez, G.; Park, Y.J.; Pauley, K.M.; Kawai, T.; Cha, S. Autoantibodies against muscarinic type 3 receptor in Sjogren's syndrome inhibit aquaporin 5 trafficking. PLoS ONE 2013, 8, e53113. [CrossRef] [PubMed]

23. Caliceti, C.; Zambonin, L.; Prata, C.; Vieceli Dalla Sega, F.; Hakim, G.; Hrelia, S.; Fiorentini, D. Effect of plasma membrane cholesterol depletion on glucose transport regulation in leukemia cells. PLoS ONE 2012, 7, e41246. [CrossRef] [PubMed] 
24. Bar-On, P.; Rockenstein, E.; Adame, A.; Ho, G.; Hashimoto, M.; Masliah, E. Effects of the cholesterol-lowering compound methyl-beta-cyclodextrin in models of alpha-synucleinopathy. J. Neurochem. 2006, 98, 1032-1045. [CrossRef]

25. Dopico, A.M.; Bukiya, A.N.; Singh, A.K. Large conductance, calcium- and voltage-gated potassium (BK) channels: Regulation by cholesterol. Pharmacol. Ther. 2012, 135, 133-150. [CrossRef] [PubMed]

26. Delporte, C.; Steinfeld, S. Distribution and roles of aquaporins in salivary glands. Biochim. Biophys. Acta 2006, 1758, 1061-1070. [CrossRef]

27. Kim, J.H.; Park, S.H.; Moon, Y.W.; Hwang, S.; Kim, D.; Jo, S.H.; Oh, S.B.; Kim, J.S.; Jahng, J.W.; Lee, J.H.; et al. Histamine H1 receptor induces cytosolic calcium increase and aquaporin translocation in human salivary gland cells. J. Pharmacol. Exp. Ther. 2009, 330, 403-412. [CrossRef]

28. Lee, K.; Choi, S.; Choi, L.M.; Lee, J.; Kim, J.H.; Chung, G.; Lee, G.; Choi, S.Y.; Park, K. Desipramine inhibits salivary Ca(2+) signaling and aquaporin translocation. Oral Dis. 2015, 21, 530-535. [CrossRef]

29. Jin, M.; Hwang, S.M.; Davies, A.J.; Shin, Y.; Bae, J.S.; Lee, J.H.; Lee, E.B.; Song, Y.W.; Park, K. Autoantibodies in primary Sjogren's syndrome patients induce internalization of muscarinic type 3 receptors. Biochim. Biophys. Acta 2012, 1822, 161-167. [CrossRef] [PubMed]

30. Oldfield, S.; Hancock, J.; Mason, A.; Hobson, S.A.; Wynick, D.; Kelly, E.; Randall, A.D.; Marrion, N.V. Receptor-mediated suppression of potassium currents requires colocalization within lipid rafts. Mol. Pharmacol. 2009, 76, 1279-1289. [CrossRef]

31. Weaver, A.K.; Olsen, M.L.; McFerrin, M.B.; Sontheimer, H. BK channels are linked to inositol 1,4,5-triphosphate receptors via lipid rafts: A novel mechanism for coupling [Ca(2+)](i) to ion channel activation. J. Biol. Chem. 2007, 282, 31558-31568. [CrossRef] [PubMed]

32. Tajima, N.; Itokazu, Y.; Korpi, E.R.; Somerharju, P.; Kakela, R. Activity of BK(Ca) channel is modulated by membrane cholesterol content and association with $\mathrm{Na}+$ /K+-ATPase in human melanoma IGR39 cells. J. Biol. Chem. 2011, 286, 5624-5638. [CrossRef] [PubMed]

33. Riddle, M.A.; Hughes, J.M.; Walker, B.R. Role of caveolin-1 in endothelial BKCa channel regulation of vasoreactivity. Am. J. Physiol. Cell Physiol. 2011, 301, C1404-C1414. [CrossRef] [PubMed]

34. Besshoh, S.; Bawa, D.; Teves, L.; Wallace, M.C.; Gurd, J.W. Increased phosphorylation and redistribution of NMDA receptors between synaptic lipid rafts and post-synaptic densities following transient global ischemia in the rat brain. J. Neurochem. 2005, 93, 186-194. [CrossRef]

35. Delint-Ramirez, I.; Salcedo-Tello, P.; Bermudez-Rattoni, F. Spatial memory formation induces recruitment of NMDA receptor and PSD-95 to synaptic lipid rafts. J. Neurochem. 2008, 106, 1658-1668. [CrossRef]

36. Hering, H.; Lin, C.C.; Sheng, M. Lipid rafts in the maintenance of synapses, dendritic spines, and surface AMPA receptor stability. J. Neurosci. 2003, 23, 3262-3271. [CrossRef]

37. Choi, T.Y.; Jung, S.; Nah, J.; Ko, H.Y.; Jo, S.H.; Chung, G.; Park, K.; Jung, Y.K.; Choi, S.Y. Low levels of methyl beta-cyclodextrin disrupt GluA1-dependent synaptic potentiation but not synaptic depression. J. Neurochem. 2015, 132, 276-285. [CrossRef]

38. Dionisio, N.; Galan, C.; Jardin, I.; Salido, G.M.; Rosado, J.A. Lipid rafts are essential for the regulation of SOCE by plasma membrane resident STIM1 in human platelets. Biochim. Biophys. Acta 2011, 1813, 431-437. [CrossRef]

39. Galan, C.; Woodard, G.E.; Dionisio, N.; Salido, G.M.; Rosado, J.A. Lipid rafts modulate the activation but not the maintenance of store-operated $\mathrm{Ca}(2+)$ entry. Biochim. Biophys. Acta 2010, 1803, 1083-1093. [CrossRef]

40. Jardin, I.; Salido, G.M.; Rosado, J.A. Role of lipid rafts in the interaction between hTRPC1, Orai1 and STIM1. Channels 2008, 2, 401-403. [CrossRef]

41. Cheng, K.T.; Liu, X.; Ong, H.L.; Ambudkar, I.S. Functional requirement for Orai1 in store-operated TRPC1-STIM1 channels. J. Biol. Chem. 2008, 283, 12935-12940. [CrossRef] [PubMed]

42. Lee, K.; Kim, Y.J.; Choi, L.M.; Choi, S.; Nam, H.; Ko, H.Y.; Chung, G.; Lee, J.H.; Jo, S.H.; Lee, G.; et al. Human salivary gland cells express bradykinin receptors that modulate the expression of proinflammatory cytokines. Eur. J. Oral Sci. 2017, 125, 18-27. [CrossRef] [PubMed]

43. Yang, H.; Zhang, G.; Cui, J. BK channels: Multiple sensors, one activation gate. Front. Physiol. 2015, 6, 29. [CrossRef] [PubMed]

44. Bukiya, A.N.; Vaithianathan, T.; Kuntamallappanavar, G.; Asuncion-Chin, M.; Dopico, A.M. Smooth muscle cholesterol enables BK beta1 subunit-mediated channel inhibition and subsequent vasoconstriction evoked by alcohol. Arterioscler. Thromb. Vasc. Biol. 2011, 31, 2410-2423. [CrossRef]

45. Bukiya, A.N.; Belani, J.D.; Rychnovsky, S.; Dopico, A.M. Specificity of cholesterol and analogs to modulate BK channels points to direct sterol-channel protein interactions. J. Gen. Physiol. 2011, 137, 93-110. [CrossRef]

46. Asakura, K.; Ueda, A.; Shima, S.; Ishikawa, T.; Hikichi, C.; Hirota, S.; Fukui, T.; Ito, S.; Mutoh, T. Targeting of aquaporin 4 into lipid rafts and its biological significance. Brain Res. 2014, 1583, 237-244. [CrossRef]

47. Sirtori, C.R. The pharmacology of statins. Pharmacol. Res. 2014, 88, 3-11. [CrossRef]

48. Habbab, K.M.; Moles, D.R.; Porter, S.R. Potential oral manifestations of cardiovascular drugs. Oral Dis. 2010, 16, 769-773. [CrossRef]

49. Pascual Cruz, M.; Chimenos Kustner, E.; Garcia Vicente, J.A.; Mezquiriz Ferrero, X.; Borrell Thio, E.; Lopez Lopez, J. Adverse side effects of statins in the oral cavity. Med. Oral Patol. Oral Cir. Bucal. 2008, 13, E98-E101.

50. Shirasuna, K.; Sato, M.; Miyazaki, T. A neoplastic epithelial duct cell line established from an irradiated human salivary gland. Cancer 1981, 48, 745-752. [CrossRef]

51. Wang, C.S.; Wee, Y.; Yang, C.H.; Melvin, J.E.; Baker, O.J. ALX/FPR2 Modulates Anti-Inflammatory Responses in Mouse Submandibular Gland. Sci. Rep. 2016, 6, 24244. [CrossRef] [PubMed] 